\title{
DINAMIKA GENANGAN PESISIR JAKARTA BERDASARKAN DATA MULTI- TEMPORAL SATELIT MENGGUNAKAN INDEKS AIR DAN POLARISASI RADAR
}

\section{DYNAMIC OF COASTAL INUNDATION IN JAKARTA BASED ON DATA MULTI- TEMPORAL SATELLITES USING WATER INDEX AND RADAR POLARIZATION}

\author{
Asmadin $^{1^{*}}$, Vincentius Paulus Siregar ${ }^{2}$, Ibnu Sofian $^{3}$, \\ Indra Jaya ${ }^{2}$, \& Antonius Bambang Wijanarto ${ }^{3}$ \\ ${ }^{1}$ Fakultas Perikanan dan Ilmu Kelautan, Universitas Halu Oleo, Kendari, 93132, Indonesia \\ ${ }^{2}$ Departemen Ilmu dan Teknologi Kelautan, FPIK-IPB University, Bogor, 16680, Indonesia \\ ${ }^{3}$ Badan Informasi Geospasial (BIG), Cibinong, Bogor, 16911, Indonesia \\ "E-mail: asmadin234@gmail.com
}

\begin{abstract}
Combining baseline data of remote sensing systems active and passive has many advantages in monitoring coastal inundation dynamically. It has advanced the surface water information gaps in coastal areas, especially areas covered by clouds and shadows. The main objective of this study was to assess the dynamics of coastal inundation in Jakarta based on multi-temporal data optics of Landsat 8 and Synthetic Aperture Radar (SAR) Sentinel 1A. The method of this research used two water index algorithms. They are Modified Normalized Difference Water Index (MNDWI) and Dynamic Surface Water Extent (DSWE) based on spectral reflectance values and empirical formulas. The other method is using the coefficient backscattering of water from a single polarization of Vertical Verticals (VV) and Vertical Horizontal (VH). The study results show that the use of both satellite data baseline of 8, 9, 15, and 16 days is quite effective, applying inundation dynamics for 8-49 days. Based on the threshold value of MNDWI >0.123 and the backscattering coefficient of $-19 d B$ are quite efficient to extract satellite data information. The empirical algorithms result in the feature of inundation, especially along the coastal dikes, reservoirs, mangrove ecosystems, and built-up lands. Satellite monitoring results show that the peak of inundation occurred on 30 May 2016 and was still visible on 15 June 2016. The combination of remote sensing methods is quite effective and efficient for monitoring inundation dynamically.
\end{abstract}

Keywords: inundation, Jakarta, landsat 8, sentinel la, polarization, water index

\begin{abstract}
ABSTRAK
Kombinasi baseline data pengindraan jauh sistem aktif dan pasif memiliki banyak keuntungan dalam pemantauan dinamika genangan pesisir. Kedua jenis sensor satelit mengatasi kesenjangan informasi genangan, terutama pada area yang ditutupi awan/bayangan. Tujuan utama penelitian ini adalah untuk mengkaji dinamika genangan di wilayah pesisir Jakarta berdasarkan data multi-temporal sensor optik dari Landsat 8 dan Synthetic Aperture Radar (SAR) Sentinel 1A. Metode penelitian ini menggunakan dua algoritma indeks air. Algoritma tersebut yaitu Modified Normalized Difference Water Index (MNDWI) dan Dynamic Surface Water Extent (DSWE) berdasarkan nilai spektral reflektansi dan formula empirik. Metode lainnya adalah menggunakan nilai rata-rata koefisien backscatter air dari analisis polarisasi tunggal Vertikal Vertikal (VV) dan Vertikal Horisontal (VH). Hasil studi menunjukkan bahwa penggunaan kedua tipe data satelit dengan baseline data 8, 9, 15 dan 16 hari cukup efektif memantau dinamika genangan selama 8-49 hari, termasuk area yang tertutup awan dan bayangan. Berdasarkan nilai threshold dari MNDWI >0,123 dan koefisien backscattering air $-19 \mathrm{~dB}$ cukup efisien digunakan untuk mengesktrak informasi data satelit. Algoritma empiris tersebut menghasilkan kenampakan genangan, terutama di sepanjang tanggul pantai, waduk, ekosistem mangrove dan lahan terbangun. Hasil pemantauan satelit menunjukkan bahwa puncak genangan terjadi pada 30 Mei 2016 dan masih terlihat pada 15 Juni 2016. Kombinasi metode pengindraan jauh tersebut cukup efektif dan efisien untuk memantau genangan secara dinamis.
\end{abstract}

Kata kunci: genangan, indeks air, Jakarta, landsat 8, polarisasi, sentinel 1a 


\section{PENDAHULUAN}

Dampak perubahan iklim global menjadikan wilayah pesisir Jakarta termasuk 10 besar kota di Asia Tenggara yang rentan terhadap tekanan lingkungan (Yusuf \& Fransisco, 2009). Jakarta merupakan salah satu kota di Indonesia yang memiliki tingkat kerentanan lingkungan laut sedang (Wibowo, 2012). Posisinya yang berada di wilayah pesisir menjadikannya sebagai kota pesisir yang paling rentan tidak hanya di Indonesia, tetapi tercatat sebagai salah satu kota paling rentan terhadap penggenangan pesisir di dunia (Sundermann et al., 2014). Semakin buruknya penurunan tanah dibandingkan dengan kenaikan muka laut lokal berpotensi memperburuk penggenangan air permukaan pesisir. Selama lebih dari lima tahun terakhir, titik-titik rawan penggenangan meningkat pesat di semua wilayah pesisir Jakarta. Kota ini sering mengalami penggenangan sepanjang tahun, meskipun pada kenaikan muka laut lokal yang relatif rendah (Sutrisno et al., 2011; Abidin et al., 2015). Air laut sudah melanda tanggul pantai dan membanjiri wilayah yang rentan di sepanjang pesisir Jakarta (Takagi et al., 2017). Pada awal Juni 2016, sejumlah tanggul pantai roboh akibat kenaikan gelombang laut, menyebabkan penggenangan air permukaan di sebagian daratan Jakarta (Ali, 2016). Hal ini berpengaruh terhadap aspek lingkungan dan ekologis (Sutrisno et al., 2011).

Fenomena penggenangan air permukaan atau banjir rob sangat spesifik dalam 10 tahun terakhir di wilayah pesisir Jakarta. Beberapa studi diantaranya melaporkan bahwa kejadian penggenangan tersebut terjadi pada 2007, 2008, 2009, 2010, 2011, 2012, 2013 dan 2014 (Simarmata, 2018), 2011 (Anggraini et al., 2012), 2013, 2014 dan 2015 lalu (Jamalludin et al., 2016). Studi tersebut menghimpun semua informasi data banjir rob dari berbagai media massa secara online. Kajian informasi genangan air permukaan dapat menggunakan kombinasi pengindraan jauh sistem aktif dan pasif sejauh ini. Dalam tiga dekade terakhir, pendekatan sistem pasif (Huang et al., 2014; Ji et al., 2009; Ouma \& Tateishi, 2006) dikembangkan dari berbagai model indeks air. Secara spesifik U.S. Geological Survey (USGS) mengembangkan produk Landsat 8 difokuskan pada genangan permukaan tanah (Jones, 2015). Landsat 8 memiliki lebih banyak kanal dan disain bandwidth yang lebih baik sebagai bentuk perbaikan teknis yang bersifat revolusioner dari generasi Landsat sebelumnya (Iron et al., 2012). Salah satu yang berkembang dari revolusi Landsat 8 ini adalah pengembangan Indeks Air (Water Index) untuk memetakan penggenangan pada piksel bebas awan/bayangan menggunakan model Dynamic Surface Water Extent (DSWE) (Jones, 2015). Model DSWE merupakan pengembangan dari indeks air Modified Normalized Difference Water Index (MNDWI) (Xu, 2006). Berbagai studi pengindraan jauh menjadikan MNDWI pilihan penting untuk diimplementasikan pada pemetaan air secara cepat di wilayah berskala besar (Ouma \& Tateishi, 2006), meskipun pendekatan ini memiliki keterbatasan-keterbatasan (Du et al., 2014). Model Dynamic Surface Water Extent merupakan pengklasifikasi tanpa pengawasan. Penetapan nilai threshold model sesuai analisis mendalam berdasarkan data spektrometri in situ dan Landsat di berbagai lokasi perairan terbuka dan parsial di Amerika Utara (DeVries et al., 2017).

Pengindraan jauh sistim pasif biasanya lebih sensitif terhadap awan/bayangan, dibandingkan dengan gangguan ionosfer yang lebih kecil pada sistem aktif C-band (Rignot \& Mouginot, 2012). Lembaga Satelit Eropa (ESA) telah meluncurkan satelit SAR Sentinel 1A (S1A) yang memiliki C-band sejak 3 April 2014. Frekuensi akusisi data dari satelit ini 12 hari, konfigurasi akuisisi sama, dan resolusi spasial 20 m (Cazals et al., 2016). Sehingga satelit ini cukup sesuai untuk menggambarkan penggenangan yang terjadi selang beberapa hari. 
Produk data S1A dinilai konsisten memberikan geolokasi yang sangat akurat yang mencerminkan keberhasilan misi sejauh ini (Schubert et al., 2015). Beberapa studi (White et al., 2015; Schumann \& Moller, 2015) merangkum beberapa metode untuk memantau perubahan tingkat air permukaan pada tanah jenuh, vegetasi tergenang, dan perubahan tutupan lahan basah. Metode ini didasarkan pada analisis interferometrik, terutama dengan multi-temporal data intensitas dan koherensi interferometri (HallAtkinson \& Smith, 2001), indeks polarisasi penuh (Novak \& Netishen, 1992; Brisco et al., 2011) atau parsial (Betbeder et al., 2014).

Kombinasi data multi-temporal SAR untuk mendeteksi penggenangan sangat menguntungkan (Lang et al., 2008; Lang \& Kasischke, 2008). Kombinasi multitemporal data Sentinel 1A dan Landsat 8 menjadi penting bagi kedua satelit dari sistem aktif dan pasif tersebut digunakan untuk mengkaji dinamika genangan air permukaan di wilayah pesisir Jakarta. Selain itu, dikembangkan beberapa model analisis ekstraksi genangan air pemukaan yang spesifik terhadap kedua satelit yang merupakan tujuan utama penelitian ini. Penerapan batas waktu (timeline) data akuisisi dari dua satelit tersebut dengan menggunakan beberapa model analisis akan meningkatkan kualitas informasi dan mengatasi kesenjangan informasi dinamika genangan, baik secara spasial maupun temporal.

\section{METODOLOGI PENELITIAN}

\subsection{Waktu dan Lokasi}

Studi ini dilaksanakan pada JuniDesember 2017 berlokasi di wilayah Jakarta (Figure 1). Daerah penggenangan biasanya terletak di wilayah pesisir Jakarta (6 $6^{\circ} 7-22^{\prime} \mathrm{S}$ dan $\left.106^{\circ} 40-55^{\prime} \mathrm{E}\right)$.

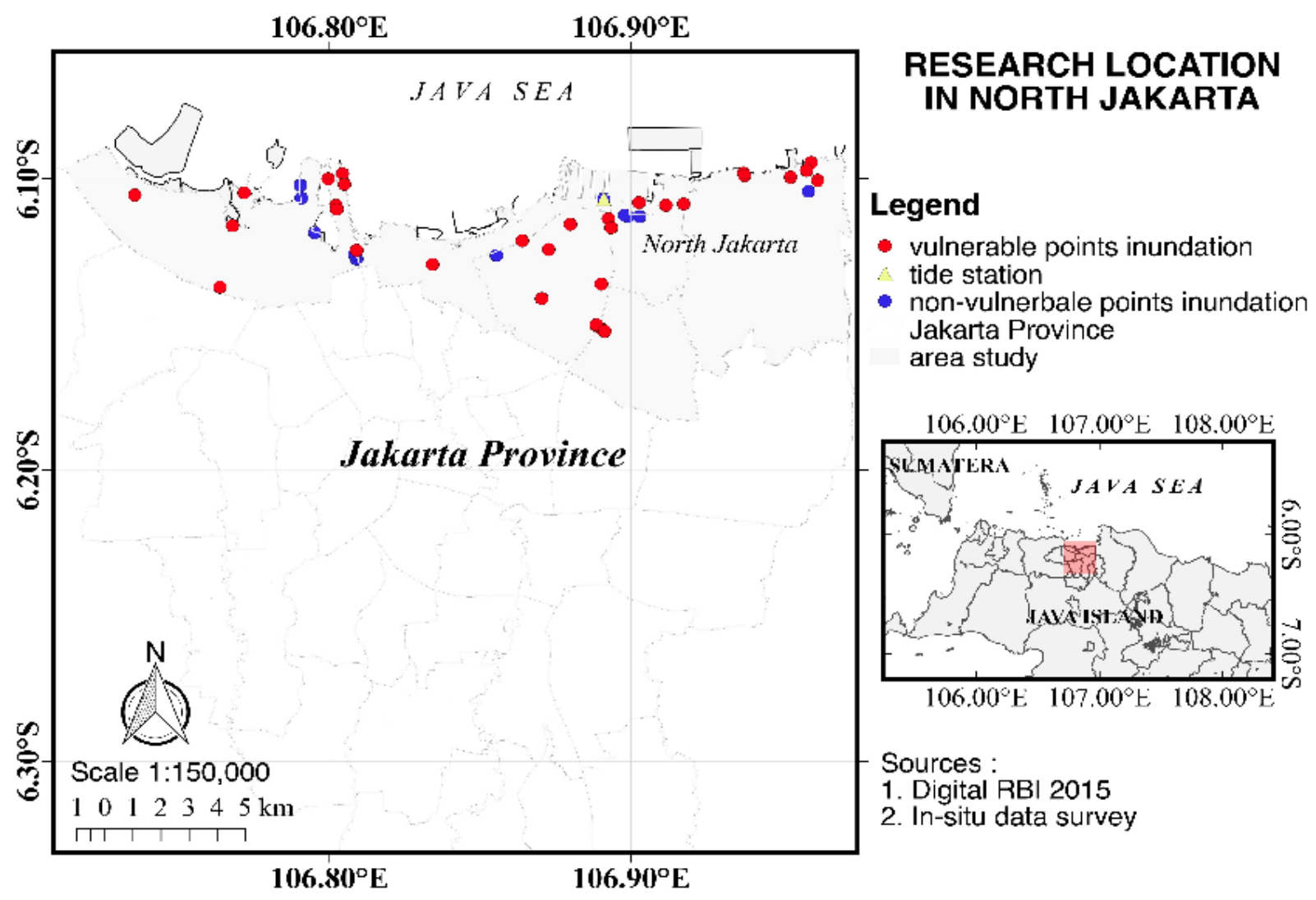

Figure 1. Research location. 


\subsection{Bahan dan Peralatan}

Bahan-bahan yang digunakan dalam studi ini, yaitu data citra multi-temporal Landsat 8 dan Sentinel 1A. Data satelit tersebut merupakan data terbuka yang didistribusikan oleh European Space Agency (ESA) melalui program Copernicus dan data yang diperoleh dari misi Landsat yang dikelola oleh National Aeronautics and Space Administration (NASA) dan US Geological Survey. Data satelit tersebut disajikan secara lengkap pada Table 1 . Produk data Landsat 8 yang digunakan biasanya mencakup data dari sensor OLI (Operational Land Imager) dan TIRS (Thermal Infrared Sensor). Produk Landsat 8 tersebut memiliki data pemantulan permukaan dari Level 1 Terrain (L1T), sebagaimana tertulis L1TP (Level-1 Terrain Precision) dalam tipe datanya. Data Landsat 8 diperoleh dari USGS yang dapat unduh secara gratis pada laman https://earthexplorer.usgs.gov. Data Sentinel 1A yang digunakan, yaitu data Ground Range Detection (GRD) diperoleh dari ESA, dapat diunduh secara terbuka pada laman https://scihub.copernicus.eu/dhus/\#/home.

Data GRD merupakan salah satu yang tersedia dari mode Interferometric Wide (IW). Mode tersebut memiliki lebar sapuan sepanjang $250 \mathrm{~km}$ dan resolusi spasial $5 \mathrm{~m} \mathrm{x}$ $20 \mathrm{~m}$. Produk GRD memperhitungkan nilai koefisien backscatter air dan objek lainnya. Satelit Sentinel 1A memiliki resolusi temporal 12 hari yang mendukung mode pencitraan tersebut dengan resolusi dan jangkauan yang berbeda (Potin et al., 2014). Keseluruhan format data Landsat 8 dan Sentinel
1A disusun dalam format Standard Archieve Format Europa (SAFE) (Irons et al., 2012) dengan resolusi temporal yang bervariasi mulai dari baseline 8 hingga 49 hari.

Perangkat keras (hardware) yang digunakan untuk pra-processing hingga postprocessing citra menggunakan satu set komputer MacBook Pro dengan RAM 8GB dan Processor Core i7. Data survei diperoleh menggunakan GPS, kamera dan lain-lain. Perangkat lunak (software) diantaranya QGIS Las Palmas versi 2.18.15 dan SNAP versi 5.0. QGIS memiliki interface dengan banyak free open source plugin. Salah satunya adalah Semi-Automatic Classification Plugin/SCP (Congedo, 2016).

\subsection{Pengolahan dan Analisis Citra}

Pengolahan citra digital Landsat 8 secara semi otomatis menggunakan plugin $\mathrm{SCP}$, terutama untuk mengunduh data secara online dan pra pengolahan (koreksi atmosferik dan konversi ke nilai reflektan). Tahap pengolahan selanjutnya, yaitu klasifikasi algoritma SAM, MNDWI, DSWE dan lainlain menggunakan QGIS. Blok diagram pengolahan citra digital tersebut disajikan pada Figure 2.

Analisis citra Landsat 8 menggunakan algoritma Indeks Air (Water Index Algorithm). Dua algoritma indeks air yang digunakan, yaitu MNDWI (Xu, 2006) dan DSWE (Jones, 2015). Persamaan kedua algoritma indeks air tersebut menggunakan nilai reflektansi spektral dan nilai threshold kanal citra Landsat 8. Kedua algoritma indeks air tersebut disajikan pada Table 2.

Table 1. Multi-temporal data of Landsat 8 and Sentinel 1A used this research.

\begin{tabular}{|c|c|c|c|c|}
\hline Platform & Sensor & $\begin{array}{c}\text { Data } \\
\text { acquisition }\end{array}$ & $\begin{array}{c}\text { Spatial } \\
\text { Resolution }\end{array}$ & Spatial Resolution \\
\hline Landsat 8 & $O L I$ & $\begin{array}{l}13 / 5 / 2016 \\
30 / 6 / 2016\end{array}$ & $\begin{array}{l}30 \mathrm{~m} \times 30 \mathrm{~m} \\
30 \mathrm{~m} \times 30 \mathrm{~m}\end{array}$ & https://earthexplorer.usgs.gov \\
\hline $\begin{array}{l}\text { Sentinel } \\
1 A\end{array}$ & $\begin{array}{l}C \text { - } \\
\text { Band } \\
S A R\end{array}$ & $\begin{array}{l}22 / 5 / 2016 \\
30 / 5 / 2016 \\
15 / 6 / 2016\end{array}$ & $\begin{array}{l}5 m \times 20 m \\
5 m \times 20 m \\
5 m \times 20 m\end{array}$ & https://scihub.copernicus.eu/dhus/\#/home \\
\hline
\end{tabular}




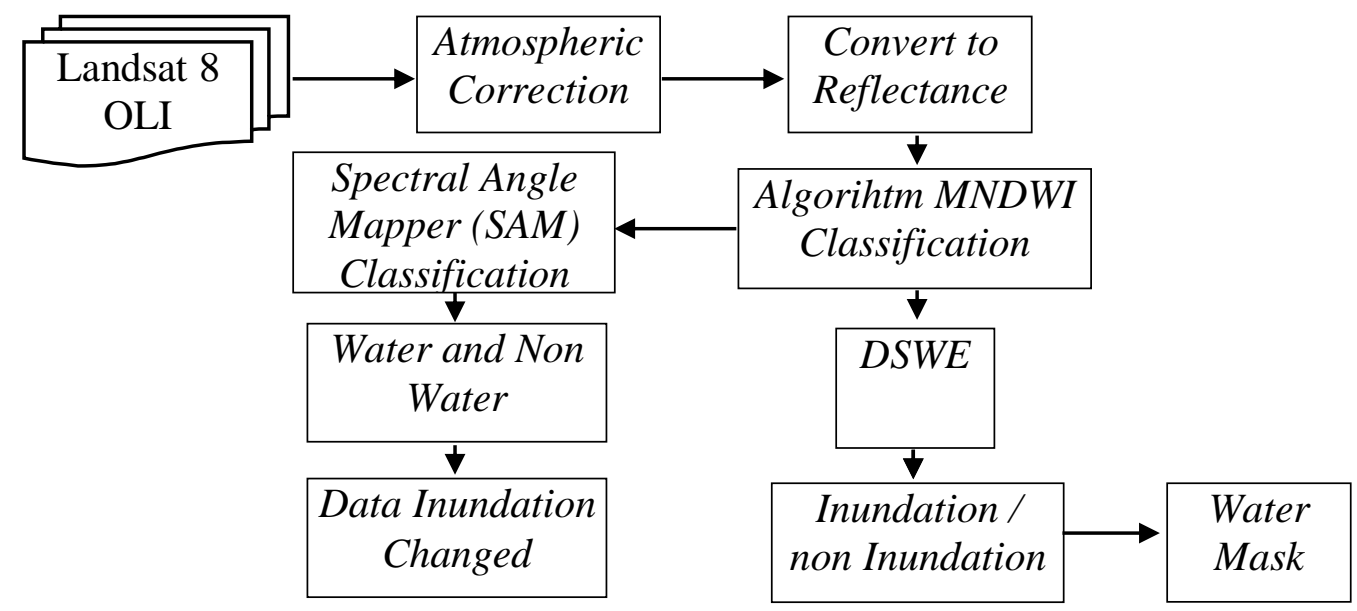

Figure 2. Inundation feature data processing on the coast of Jakarta using Landsat 8 Imagery.

Table 2. Water index formula used.

\begin{tabular}{lll}
\hline Water indexes & Formula & Reference \\
\hline$M N D W I$ & $($ Green $-M I R) /($ Green + MIR $)$ & Xu (2006) \\
$D S W E$ & $(M N D W I>0.123)$ or & Jones (2015) \\
& $M N D W I>-0.5$ and NIR $<0.2$ and $S W I R<0.1$ & \\
\hline
\end{tabular}

Pengolahan data radar Sentinel 1A menggunakan beberapa tool yang ada di aplikasi SNAP. Data yang diunduh dalam format. SAFE memiliki kapasitas sangat besar (sekitar 8GB), yang terdiri dari 3 subset Interferometric Wave (IW), sehingga tool S1 TOPS Split akan menentukan pilihan salah satu subset sesuai area studi. Teknik ini untuk merekonstruksi area studi dan mereduksi kapasitas data yang sangat besar. Tool selanjutnya adalah langkah inline SNAP untuk memperoleh file orbit satelit menggunakan Apply Orbit File. Biasanya lintasan orbit terbang satelit terdeteksi oleh banyak sensor, seperti gyro yang terpasang, GPS, dan juga pengamatan di darat. Data orbit dihitung tepat membutuhkan waktu, sehingga data orbit yang tepat tidak termasuk dalam banyak bundel data satelit SAR. SNAP mendapatkan data orbit yang lebih tepat untuk membantu meningkatkan geocoding dan hasil pemrosesan SAR lainnya. Metode sintetis yang digunakan untuk membuat citra SAR juga memiliki kelemahan.
Gangguan yang merusak gelombang SAR biasanya mengakibatkan citra SAR mengalami noise. Noise citra SAR disebut "bintik" atau "speckle". Pengurangan speckle noise dilakukan dengan menggunakan filter tunggal yang tersedia di SNAP. Pengolahan data Sentinel 1A dalam bentuk file ZIP biasanya citra aslinya terbalik di software SNAP, ditampilkan sesuai urutan perolehan data yang tidak sesuai dengan representasi kartografi, sehingga dilakukan re-proyeksi citra dari sensor geometri ke proyeksi geografis menggunakan koreksi topografi (terrain correction). Pengaruh sudut datang (incidence angle) yang diterima sinyal signifikan (Schumann \& Moller, 2015) terutama pada mode operasi sensor yang menggunakan petak jalur orbit (O'Grady et al., 2013; 2014). Oleh karena itu, diperlukan koreksi incidence angle. Diagram pemrosesan data multi-temporal radar SAR Sentinel 1A disajikan pada Figure 3.

Analisis Synthetic Aperture Radar 


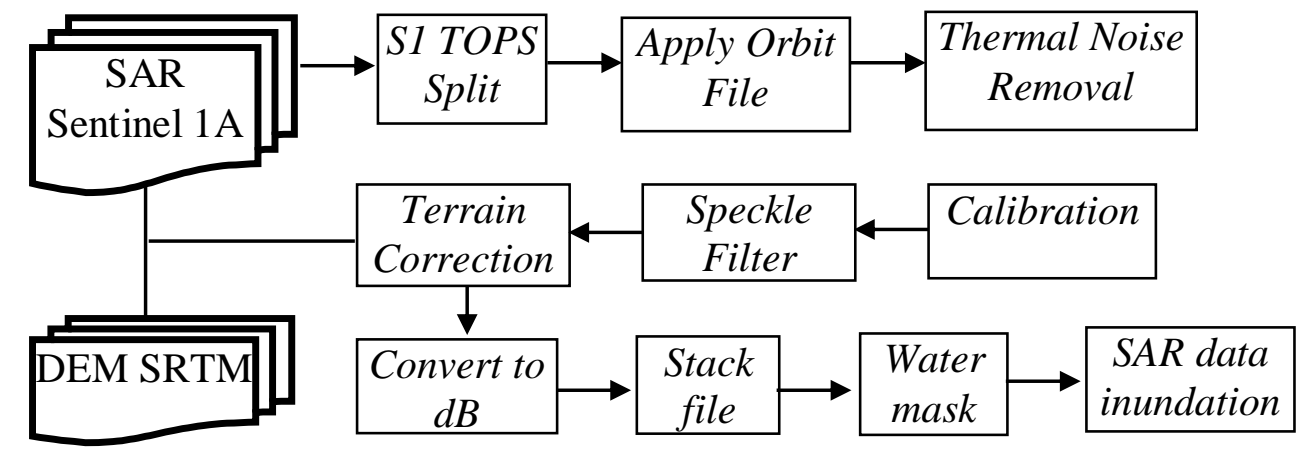

Figure 3. InSAR Sentinel 1A processing diagram to detect coastal inundation in Jakarta.

(SAR) menggunakan analisis polarisasi penuh (Brisco et al., 2011) atau parsial (Betbeder et al., 2014). Analisis polarisasi tunggal $\mathrm{VV}$ dan $\mathrm{VH}$, atau dual polarisasi $\mathrm{VV}+\mathrm{VV}$ dan $\mathrm{VH}+\mathrm{VV}$ menggunakan data intensitas (intensity) yang dikonversi ke dalam satuan decible $(\mathrm{dB})$. Persamaan koefisien backscattering $\sigma^{\circ}(d B)=10 . \log _{10} \sigma^{\circ}$ biasanya dalam satuan dB. Selanjutnya koefisien backscatter $\sigma_{(d B)}^{\circ}$ dinormalisasi menjadi $\sigma^{\circ}{ }_{(d B)}=\frac{\sigma}{A_{i}}$, dimana $A_{i}=$ area yang terkait objek yang dikaji (Ferretti et al., 2007).

\subsection{Validasi Akuisisi Data}

Beberapa metode validasi citra, diantaranya dengan menggunakan hasil pengukuran gerak naik turunnya muka air laut selama bulan September 2016 menggunakan MOTIWALI (Mobile Tide Water Level Instrument). Instrumen pasang surut tersebut dikembangkan oleh Laboratorium Instrumentasi Departemen ITK, FPIK IPB University (http://teknologi-kelautan.com). MOTIWALI tersebut ditempatkan di rumah pasut BIG, stasiun Kolinlamil Jakarta. Seterusnya dianalisis prediksi pasang surut 29 piantan menggunakan GUI MATLAB Tide Level: Prediction 2010 versi 1 (Boon, 2007). Hasil analisis data pasang surut tersebut digunakan untuk memprediksi kenaikan laut rata-rata, ketinggian air laut tertinggi dan kenaikan air laut selama periode akuisisi citra dan fenomena pasut pada Mei-
Juni 2016. Selain itu, dilakukan penelusuran informasi dari berbagai sumber media informasi secara online dan survei langsung, termasuk memeriksa sebagian tanggul waduk dan tanggul pantai di Jakarta.

\section{HASIL DAN PEMBAHASAN}

\subsection{Hasil Analisis Indeks Air Menggunakan Data Multi- Temporal Landsat 8}

Hasil studi menunjukkan bahwa algoritma MNDWI meningkatkan nilai reflektansi air bernilai positif. Kondisi tersebut ditunjukkan dari kenampakan dan nilai reflektan air pada Figure 4. Nilai reflektansi air menunjukkan makin positif dan objek lainnya negatif. Objek badan air, pencampuran air pada ekosistem mangrove, dan objek non air yang berwarna merah tampak jelas sebelum tergenang pada citra akusisi 13/5/2016 dibandingkan setelah penggenangan pada citra akuisisi 30/6/2016. Berdasarkan hasil modifikasi NDWI, nilai reflektansi air sebesar 0,478 diperoleh dari data citra akuisisi sebelum penggenangan berlangsung. Modifikasi model tersebut (MNDWI) meningkatkan nilai reflektansi air sebesar 0,129 yang diekstrak dari algoritma NDWI. Peningkatan nilai reflektansi air sebesar 0,493 juga diperoleh pada citra akusisi setelah penggenangan dengan nilai 0,2 menggunakan algoritma NDWI. Selain itu, modifikasi model NDWI juga meningkatkan nilai reflektansi pencampuran air dan objek 
lainnya sebelum dan setelah genangan masing-masing bernilai negatif, yaitu $-0,169$ dan $-0,127$ menjadi 0,004 dan 0,163 . Nilai pencampuran ini merupakan kelas parsial air yang dipengaruhi oleh objek lain, misalnya awan. Awan/bayangan dan atau sedimentasi bercampur air terdeteksi berwarna kekuningan pada gambar tersebut.

Nilai reflektan MNDWI ini sesuai studi Xu (2006) menunjukkan kemampuan algoritma tersebut di pesisir Jakarta menghasilkan beberapa hal, yaitu (i) air memiliki nilai reflektansi positif lebih besar, karena menyerap lebih banyak cahaya MIR daripada cahaya NIR; dan (ii) lahan terbangun dan tanah dan vegetasi memiliki nilai negatif. Tanah lebih mencerminkan cahaya MIR daripada cahaya NIR dan vegetasinya

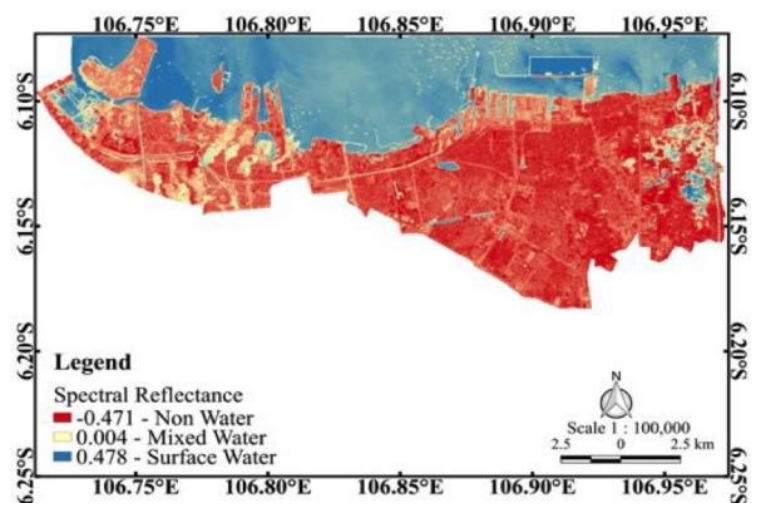

Before inundation -

Data acquisition of 13/5/2016 mencerminkan cahaya MIR masih lebih banyak dari pada cahaya hijau. Kontras antara air dan tanah buatan MNDWI sangat diperbesar oleh peningkatan nilai reflektansi air dan penurunan nilai lahan yang dibangun dari yang positif ke negatif. Peningkatan nilai reflektan air makin negatif pada citra MNDWI lebih jelas, seperti air terbuka, sedangkan tanah, tanah dan vegetasi yang dibangun di seluruh nilai negatif dan karenanya dapat ditekan dan bahkan dibuang. Sedangkan nilai reflektansi negatif merupakan objek bukan air atau pencampuran air dan objek lainnya.

Berdasarkan nilai spektral MNDWI yang diklasifikasi menggunakan model SAM, menunjukkan pola lokasi air permukaan sesuai klasifikasi MNDWI, seperti

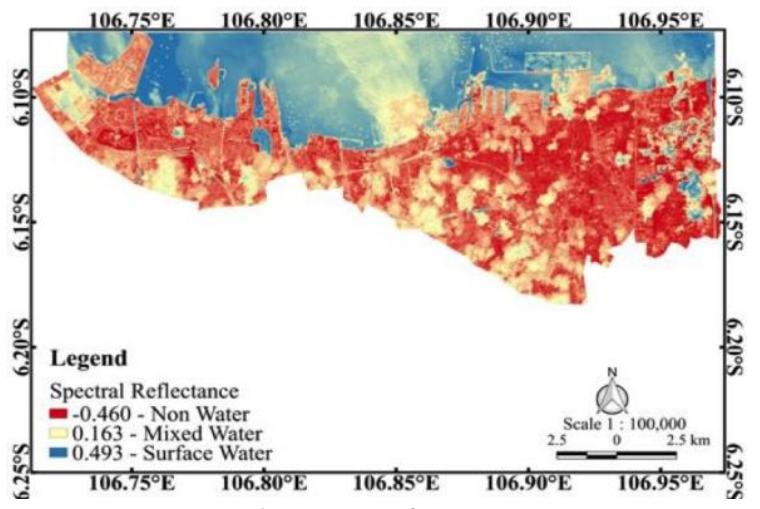

After inundation -

Data acquisition of 30/6/2016

Figure 4. The results of the MNDWI algorithm for multi-temporal data Landsat 8.

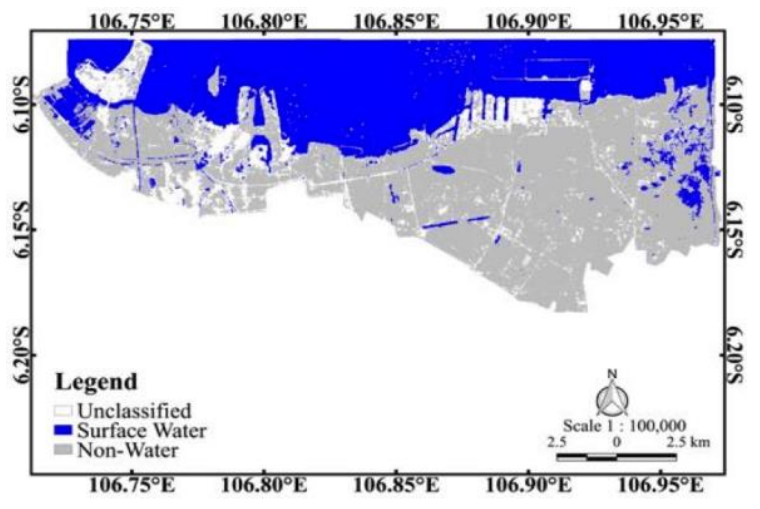

Before inundation -

Data acquisition of 13/5/2016

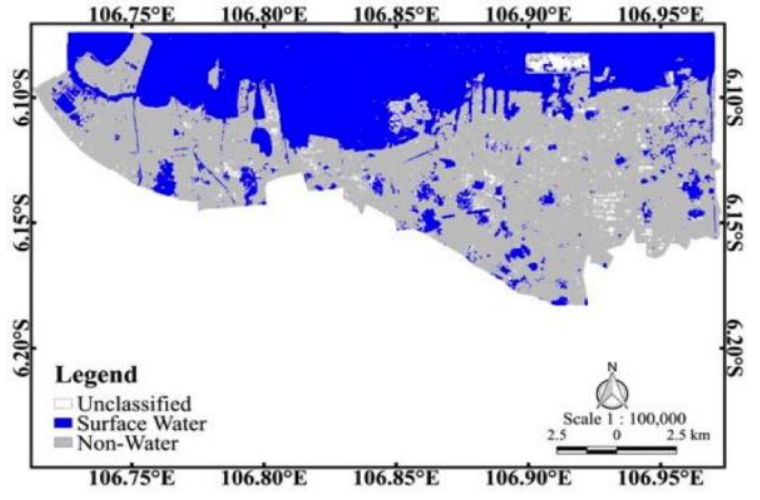

After inundation -

Data acquisition of 30/6/2016

Figure 5. The results of the SAM algorithm for multi-temporal data Landsat 8. 
ditunjukkan Figure 4. Teknik pembelajaran secara supervised SAM menggunakan threshold 20 berdasarkan 30 kelas yang dibentuk nilai spektral ROI air, non air, awan/ bayangan citra MNDWI. Perubahan kenampakan badan air, air dan non air lebih signifikan setelah penggenangan dibandingkan sebelum penggenangan. Kedua algoritma MNDWI dan SAM cukup baik diterapkan di wilayah pesisir tropik, seperti Jakarta untuk memverifikasi objek air permukaan dan lainnya.

Penerapan algoritma DSWE (Jones, 2015) menggunakan nilai threshold MNDWI dan NIR dan SWIR menunjukkan performa yang berbeda untuk menggambarkan penggenangan air permukaan pesisir Jakarta. Performa tersebut disajikan pada Figure 6. Nilai threshold MNDWI >0,123 menunjukkan performa lebih baik terhadap air permukaan. Perubahan penggenangan

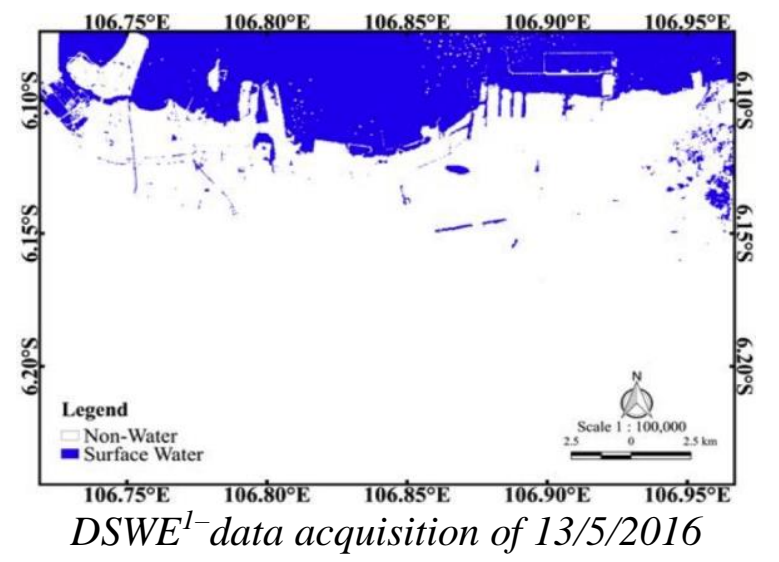

(Before inundation)

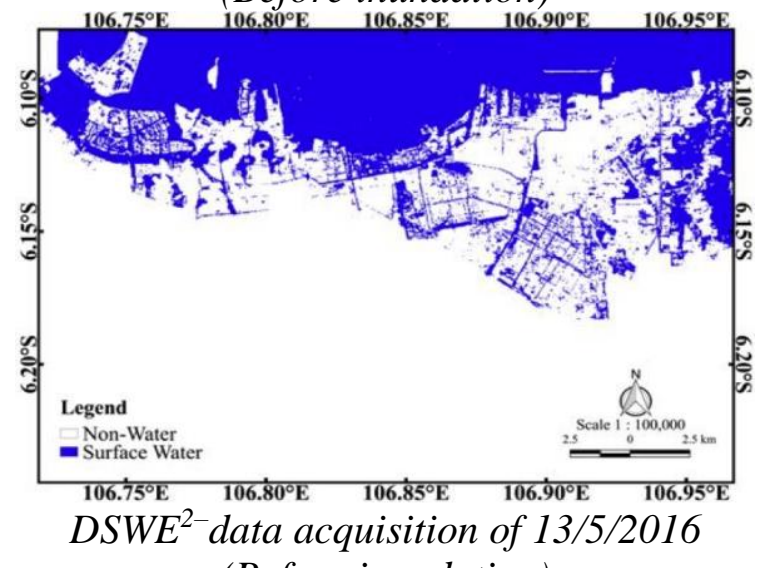

(Before inundation) permukaan makin tidak terlihat dengan jelas menggunakan formula $\mathrm{DSWE}^{2}=\mathrm{MNDWI}>$ 0,5 AND NIR $<0,2$ AND $\quad \mathrm{SWIR}<0,1$. DSWE $^{2}$ menggunakan kombinasi antara kanal GREEN, MIR, NIR dan SWIR. Seperti halnya MNDWI dan SAM, algoritma DSWE $^{1}$ dan DSWE ${ }^{2}$ tidak dapat menghilangkan noise awan/bayangan secara efektif di beberapa tempat. Penerapan nilai threshold DSWE $^{2}$ ditentukan secara empirik dan teruji dengan tingkat kepercayaan $>70 \%$ di perairan sub tropik, Amerika Utara (Jones, 2015), tetapi penerapannya di pesisir tropik seperti Jakarta hasilnya kurang optimal dibandingkan DSWE ${ }^{1}$. Nilai threhold 0,123 merupakan data reflektansi permukaan Landsat yang diuji pada 50 citra Landsat dengan berbagai kondisi awan, untuk musim hujan dan kering selama 11 tahun di Amerika Utara (DeVries et al., 2017).
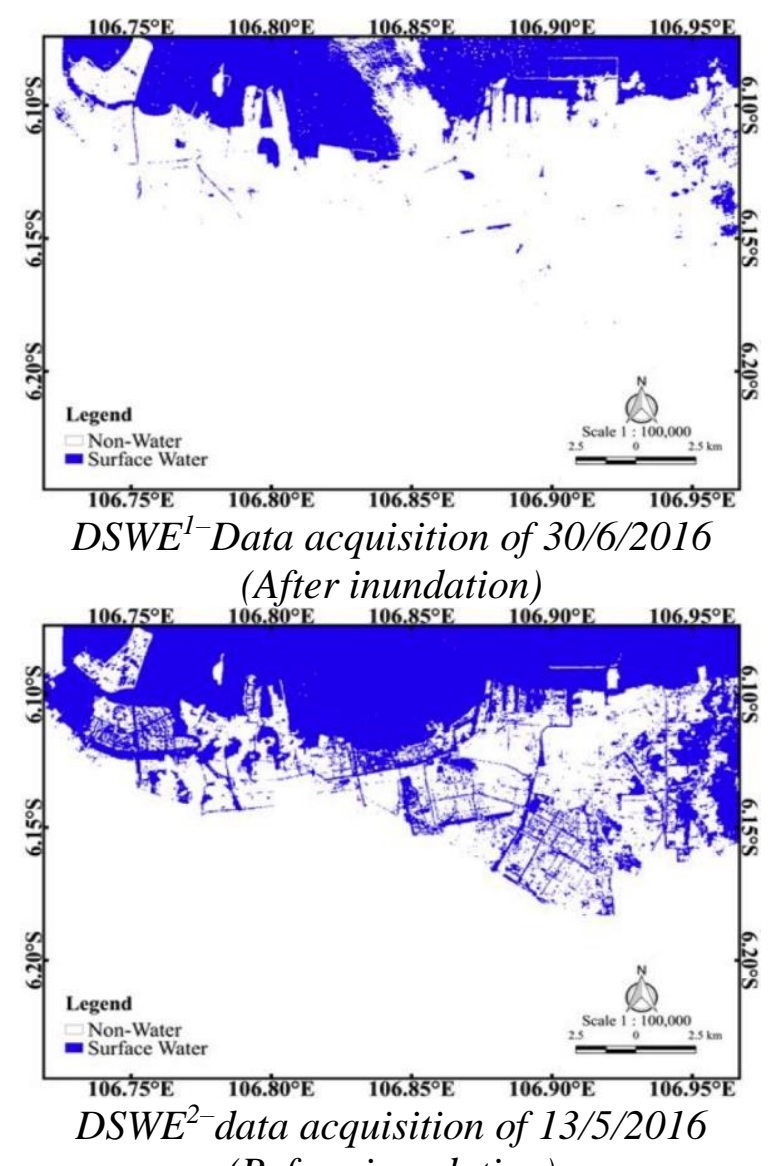

(Before inundation)

Figure 6. The results of the DSWE algorithm for multi-temporal data Landsat 8. 


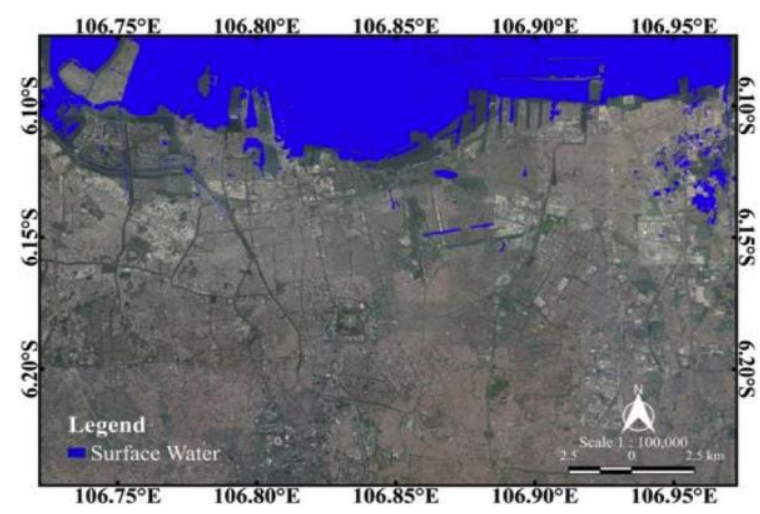

(a) Data acquisition of 13/5/2016

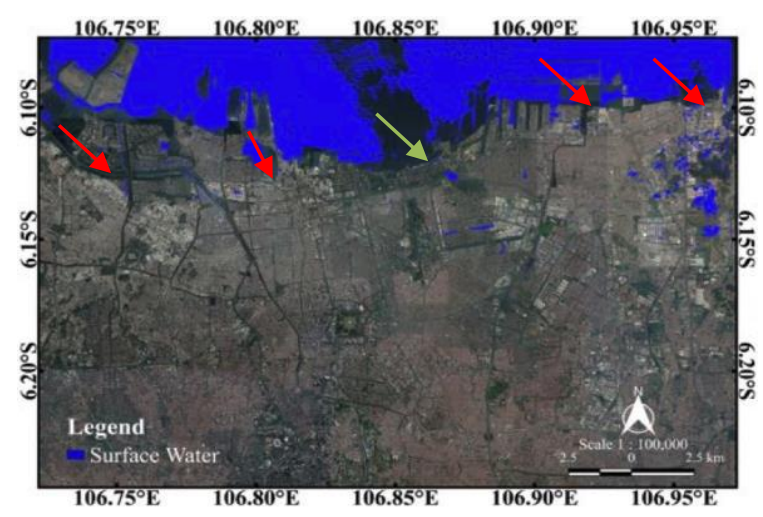

(b) Data acquisition of 30/6/2016

Figure 7. The spatial dynamic (a) before and (b) after inundation in Jakarta coastal based on water masking technique from the DSWE algorithm overlaid Google Earth.

Karakterisasi spektral reflektan satelit Landsat umumnya menunjukkan nilai threshold air bernilai positif atau $\geq 0$ (McFeeters, 1996; Jones, 2015). Penetapan nilai threshold $=0$ tersebut dalam algoritma MNDWI menghasilkan informasi yang kurang optimal (Asmadin et al., 2018). Oleh karena itu, melalui penetapan statis nilai threshold air > 0.123 yang sama mengacu pada Jones (2015), diterapkan dalam beberapa studi (DeVries et al., 2017; Carroll \& Loboda, 2017) menghasilkan klasifikasi piksel air yang tinggi, moderat, parsial (air yang dikombinasikan dengan vegetasi dan/ atau fraksi tanah), dan bukan air.

Dalam studi ini algoritma DSWE menggeneralisasi air permukaan dan objek lainnya. Melalui proses masking terhadap nilai threshold air permukaan menggunakan DSWE $^{1}$, performa penggenangan air permukaan tampak jelas setelah ditumpangsusun dengan Google Earth (Figure 7). Perubahan tersebut diasumsikan tidak adanya noise awan/bayangan. Penggenangan air permukaan terdeteksi di wilayah ekosistem mangrove, lahan terbangun dan badan air yang ditunjukkan tanda anak panah (merah). Perubahan setelah penggenangan tampak pencampuran kelas air parsial, yaitu air dan hasil sedimentasi, seperti ditunjukkan tanda anak panah berwarna hijau. Sebagian dari area studi mengalami pencampuran kelas air parsial dengan awan. Hasil studi ini relevan dengan studi Carroll \& Loboda (2017) di mana perbaikan pada kelas "air parsial" juga memiliki implikasi penting terhadap peningkatan deteksi awan. Peningkatan jumlah keseluruhan pengamatan air permukaan sangat dipengaruhi kelas air parsial ini. Kondisi ini perlu penyempurnaan terhadap penerapan DSWE, terutama di area studi.

\subsection{Hasil Analisis Polarisasi Meng- gunakan Data Multi-Temporal Sentinel 1A}

Polarisasi menggambarkan orientasi komponen medan listrik dari gelombang elektromagnetik. Polarisasi memberikan diskriminasi yang lebih baik dari berbagai jenis permukaan dan meningkatkan pengenalan dan deteksi objek (Brisco et al., 2011). Hasil analisis polarisasi tunggal data akuisisi 22/5/2016, 30/5/2016 dan 15/6/2016 SAR Sentinel 1A menunjukkan performa radar bebas awan dan bayangan untuk mendeteksi air permukaan. Hal ini sangat berbeda dengan hasil analisis indeks air MNDWI yang dikemukakan sebelumnya.

Kenampakan air permukaan tampak berwarna biru tersebar di area sekitar vegetasi mangrove, waduk, tanggul dan area lahan terbangun di sepanjang wilayah pesisir Jakarta. Pencampuran air+vegetasi tergenang juga terdeteksi. Hasil analisis polarisasi tunggal dalam citra terrain tampak kuantitas objek air berbeda antara polarisasi VV dan 
VH. Hasil analisis polarisasi tunggal VV dan VH menunjukkan bahwa nilai intensitas air berkisar -16 sampai $-22 \mathrm{~dB}$. Nilai intensitas air dan objek lainnya yang dideteksi SAR Sentinel disajikan pada Figure 9. Kisaran nilai tersebut relevan dengan studi Amitrano et al. (2014) sebesar -17 dB untuk memonitoring perairan waduk (reservoir) di Italia. ESA menetapkan nilai intensitas objek air sebesar -19 dB. Nilai tersebut merupakan
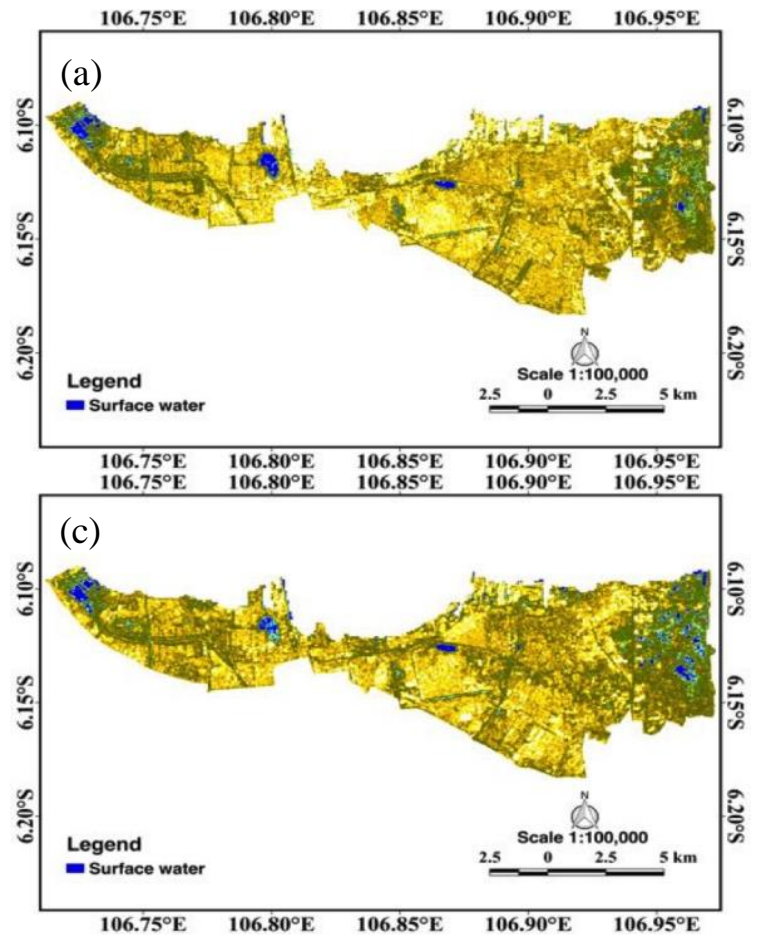

nilai rata-rata intensitas objek air dalam studi ini. Kedalaman penetrasi gelombang radar bervariasi terhadap polarisasi dan akuisisi yang berbeda. Dalam kasus penelitian ini, polarisasi memberikan informasi tentang berbagai lapisan target, misalnya reservoir atau vegetasi yang tergenang. Polarisasi memberikan informasi tentang bentuk dan orientasi elemen hamburan kecil yang menyusun permukaan atau target.
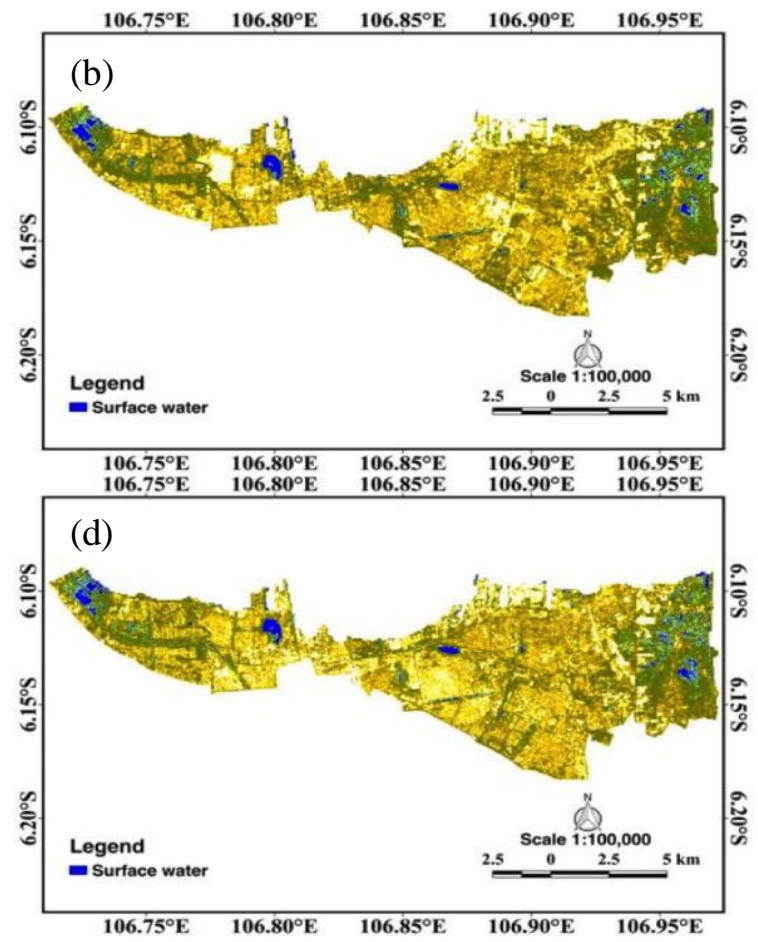

Figure 8. Result of single polarization VV analysis from GRD SAR Sentinel 1A converted into decibel unit (dB) products acquisition: (a) 22/5/2016, (b) 30/5/2016, and (d) 15/6/2016, and from polarization VH data acquisition of (c) 30/5/2016 in the coastal area of Jakarta.

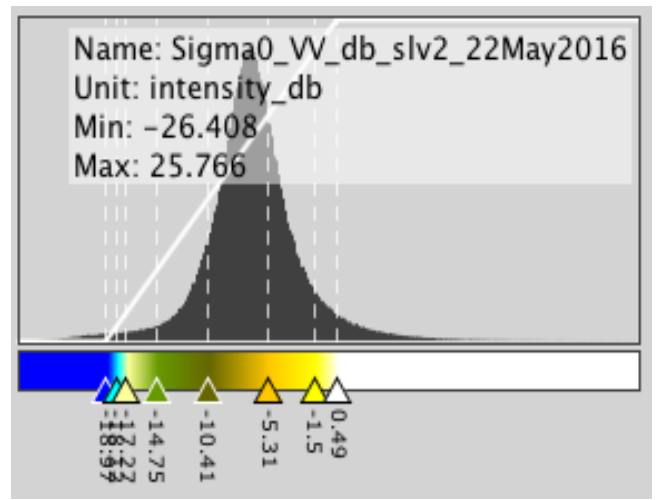

(a) VV Polarization

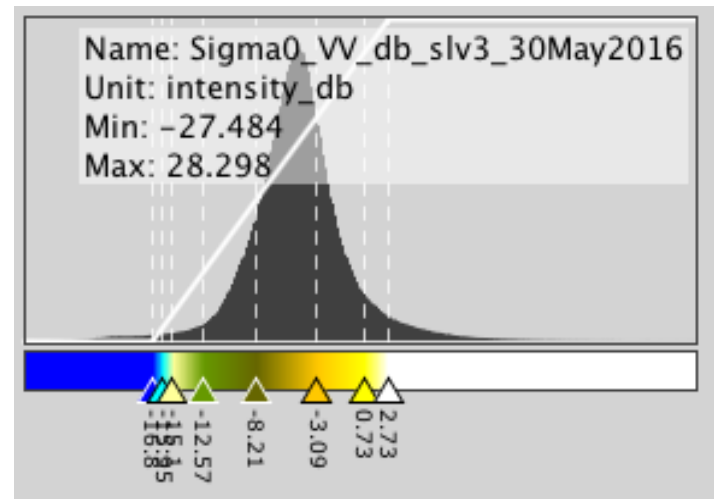

(b) VV Polarization 


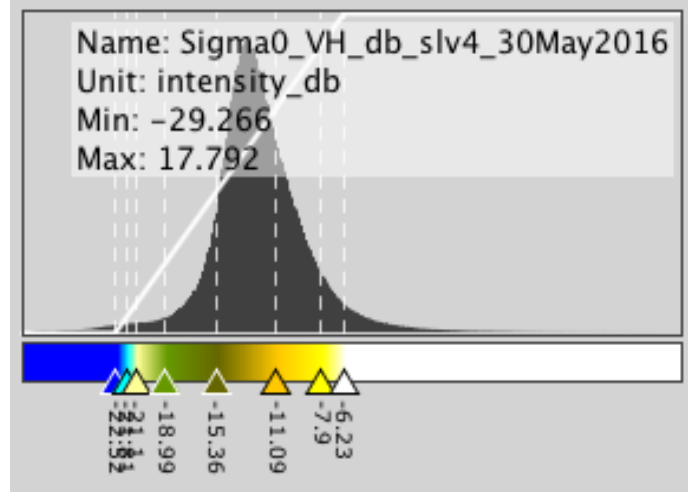

(c) VH Polarization

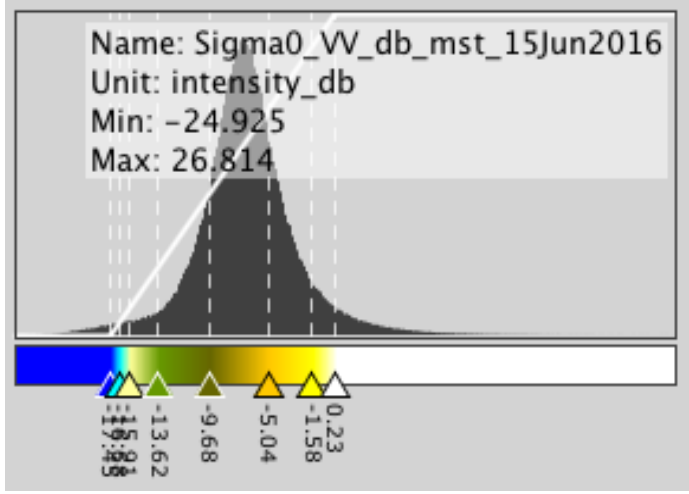

(d) VV Polarization

Figure 9. Histogram of the sigma naught () of the water, and non-water objects from single polarization $V V$ analysis from GRD SAR Sentinel 1A products acquisition: (a) 22/5/2016, (b) 30/5/2016, and (d) 15/6/2016, and from polarization VH data acquisistion of (c) 30/5/2016 in the coastal area of Jakarta.

Data akuisisi SAR Sentinel 1A dengan baseline 8-24 hari sangat memungkinkan digunakan untuk memantau air permukaan. Baseline 12 hari merupakan periode akuisisi terbaik SAR Sentinel 1A (Cazals et al., 2016). Baseline 8 hari selama periode 22/5/2016-30/5/2016 memberikan manfaat yang lebih besar dari baseline 16 hari (30/5/2016-15/6/2016) untuk memantau lahan basah atau daerah genangan di wilayah pesisir Jakarta. Hasil analisis polarisasi VV dan VH data akuisisi 30/5/2016 menunjukkan bahwa penggenangan sudah terjadi sejak akhir Mei 2016. Kondisi air permukaan tampak lebih luas pada polarisasi VH data akuisisi 30/5/2016 dibandingkan data akuisisi lainnya. Lebih dari satu pantulan backscattering cenderung mendepolarisasi pulsa, sehingga pengembalian polarisasi silang dalam kasus ini lebih besar daripada dengan pantulan tunggal. Performa sistem transmisi $\mathrm{V}$ dan penerima $\mathrm{H}$ menunjukkan lebih baik dibandingkan transmisi $\mathrm{V}$ dan penerima $\mathrm{V}$.

Dinamika penggenangan air permukaan di wilayah pesisir Jakarta selama periode akuisisi citra SAR Sentinel 1A tersebut disajikan pada Figure 10. Perubahan bentuk dan orientasi air permukaan tampak jelas melalui proses masking air menggunakan nilai intensitas $-19 \mathrm{~dB}$. Nilai intensitas ter- sebut digunakan dalam kombinasi polarisasi $\mathrm{VV}+\mathrm{VH}$ dapat menunjukkan deteksi area yang tergenang lebih terlihat dengan jelas berdasarkan analisis backscatter yang ditampilkan melalui virtual kanal merah. Gelombang radar sangat tercermin dari permukaan air. Sinyal radar memiliki variabilitas yang tinggi pada badan air, rawa dan sekitar vegetasi tergenang seperti mangrove, karena kemampuan radar menembus vegetasi dan mendorong berbagai jenis mekanisme hamburan.

Penggenangan terjadi di hampir semua kecamatan di Jakarta Utara sebagaimana ditunjukkan pada virtual merah pada hasil polarisasi $\mathrm{VH}$ akusisi 30 Mei 2016 (Figure 10). Penggenangan terdeteksi pada sekitar area lahan terbangun, vegetasi mangrove dan badan air. Kondisi tanggul pantai cukup efektif membatasi naiknya air laut, jika pertahanan pantai tersebut berfungsi dengan baik. Berdasarkan penelusuran studi menunjukkan bahwa beberapa pertahanan pantai tidak berfungsi optimal, sehingga menjadi penyebab genangan terjadi. Beberapa hal teridentifikasi karena (i) sebagian garis pantai di wilayah Kecamatan Penjaringan dan Cilincing tidak memiliki tanggul permanen (Kelurahan Penjaringan, Muara Angke); (ii) tanggul permanen yang tersedia relatif rendah dan ada beberapa ba- 

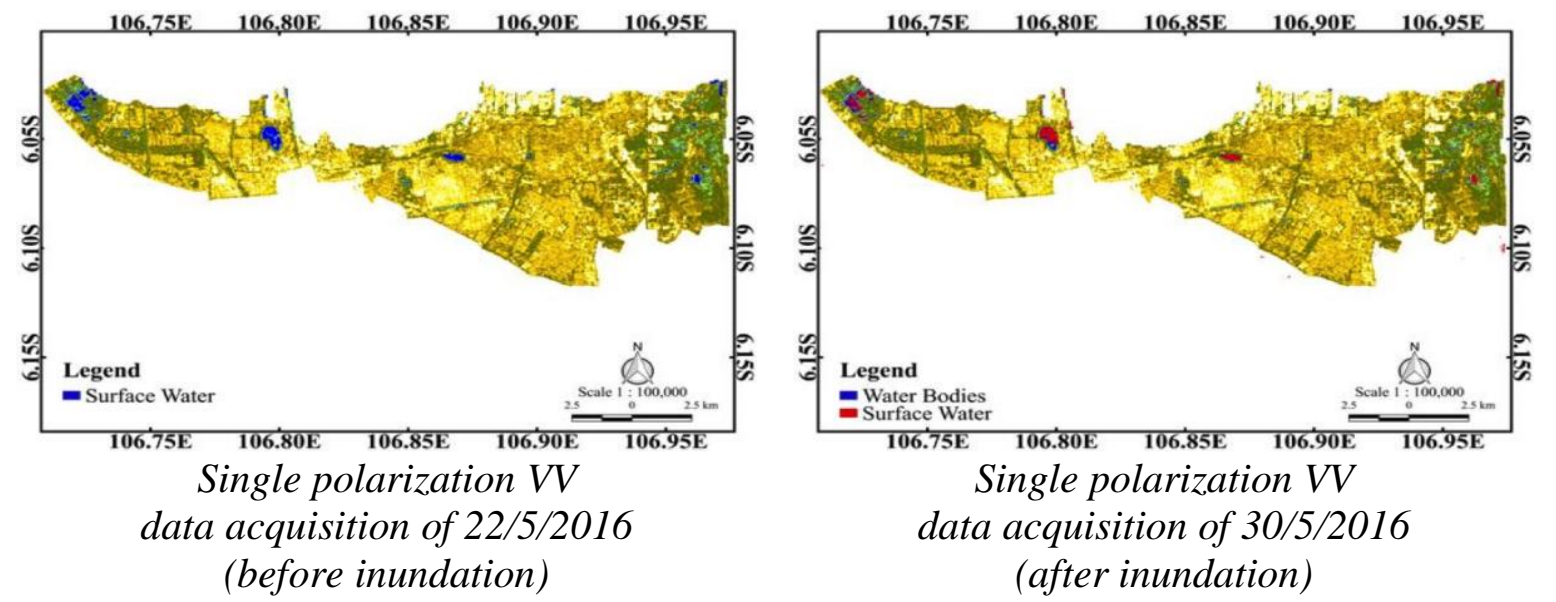

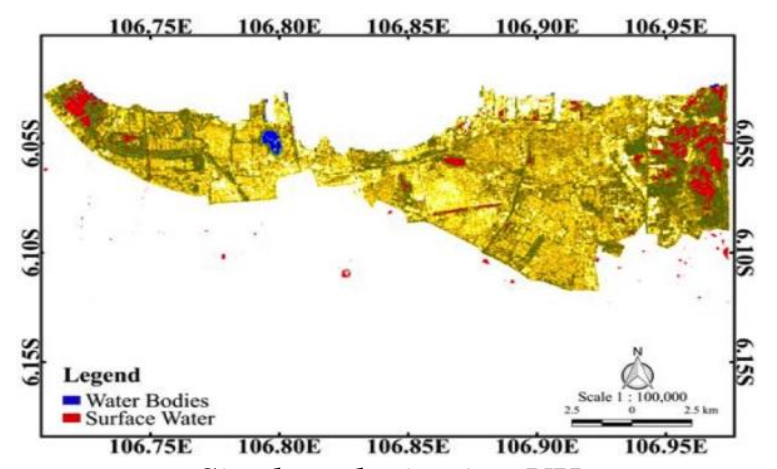

Single polarization $\mathrm{VH}$

data acquisition of 30/5/2016 (after inundation)

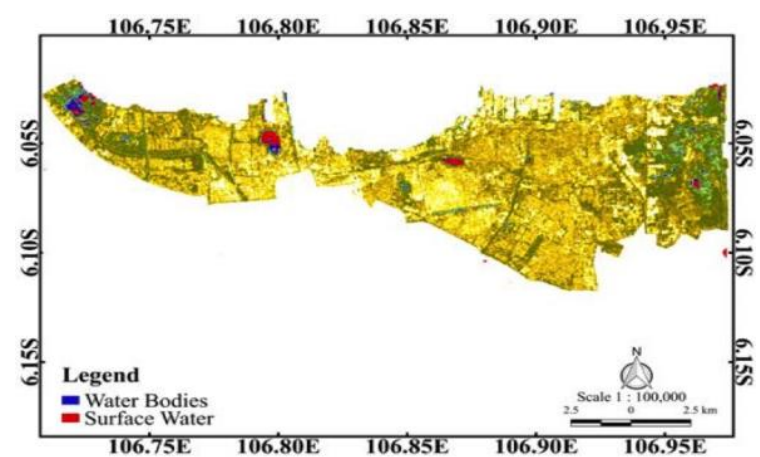

Single polarization $\mathrm{VV}$

data acquisition of 15/6/2016

(after inundation)

Figure 10. The spatial variation of the coastal inundation in Jakarta using an average backscattering coefficient of water of $-19 \mathrm{~dB}$.

gian tanggul utama roboh (Kapuk Muara, Pluit, Kamal Muara). Kondisi tersebut makin diperparah dengan dampak kenaikan gelombang pasang ekstrim yang terjadi selama akhir Mei 2016 yang menyebabkan robohnya sejumlah tanggul seperti disajikan pada Table 3. Akibatnya air laut mengalir masuk melalui celah-celah tanggul dan menggenangi pemukiman warga wilayah sekitar pantai Mutiara, pasar ikan Muara Angke dan Muara Baru Penjaringan selama beberapa puluh hari (https://www.liputan6.com). Selama periode tersebut, ketinggian genangan mencapai 0,30-0,80 m. Hal ini menunjukkan bahwa ancaman penggenangan akibat kenaikan air laut terutama terjadi di wilayah pesisir Jakarta.

Fakta fisik tanggul penahan yang jebol pada beberapa bagian mengakibatkan air laut masuk melalui celah-celah tanggul yang jebol tersebut sejak akhir Mei 2016 (Ramdani, 2017). Hasil penelitian menunjukkan bahwa akibat kenaikan gelombang air pasang yang terjadi selama beberapa hari berturut-turut menyebabkan ukuran tanggul jebol bertambah besar. Puncak tanggul jebol terjadi pada awal Juni 2016. Hasil prediksi pasut yang terjadi selama periode 29/5/2016 hingga 2/6/2016 menunjukkan nilai pasang tertinggi berkisar antara 0,90-1,00 m. Hasil penelitian menunjukkan bahwa pada awal Juni 2016, kenaikan air pasang relatif lebih rendah berkisar 0,78-0,84 m. Meskipun kenaikan air pasang relatif rendah, seperti ditunjukkan pada Table 3, proses tidal asimetris melalui pergerakan air surut kembali 
membutuhkan waktu lebih lama dari 4 jam. Fakta data tersebut dibuktikan melalui hasil analisis harmonik sebagaimana disajikan dari gerak osilasi pasang surut harian pada Figure 11. Berdasarkan grafik, terutama pada Figure 11c sebagai periode awal masuknya air laut menunjukkan bahwa kenaikan air laut dari level tertinggi hingga air surut kembali mencapai lebih dari 5 jam dari kenaikan muka laut rata-rata. Kondisi ini berlangsung sama sekitar 2 minggu, di mana
Fakta data tersebut dibuktikan melalui hasil masih ditemukan adanya area tergenang hingga 15 Juni 2016. Selain antisipasi kenaikan muka laut rata-rata belum optimal, karena sejumlah tanggul pantai belum direvitalisasi. Beberapa hal lain yang juga memperburuk genangan di wilayah pesisir Jakarta adalah elevasi lahan pesisirnya sebagian besar berada di bawah permukaan laut, elevasi pantai cukup landai, dan area penggenangan terdiri dari lapisan tanah kedap air.

Table 3. Location of the collapsed dikes, estimated inundation height, and high tide level on the coast of Jakarta during early June 2016.

\begin{tabular}{|c|c|c|c|}
\hline Date/Days & Locations & $\begin{array}{c}\text { Height of } \\
\text { inundation }(m)\end{array}$ & $\begin{array}{l}\text { Height of } \\
\text { tide }(m)^{*}\end{array}$ \\
\hline$\overline{6 / 3 / 2016(\text { Friday) }}$ & Mutiara bays & $0.30-0.50$ & 0.84 \\
\hline 6/4/2016 (Saturday) & Muara Angke Penjaringan & 0.40 & 0.79 \\
\hline 6/5/2016 (Sunday) & $\begin{array}{l}\text { East side of the Muara Baru } \\
\text { Penjaringan dikes (Near TPI) }\end{array}$ & 0.50 & 0.78 \\
\hline 6/6/2016 (Monday) & $\begin{array}{l}\text { Reservoir dikes of Muara Angke } \\
\text { Penjaringan }\end{array}$ & 0.80 & 0.79 \\
\hline
\end{tabular}

*Result of tide prediction analysis from in-situ data of MOTIWALI in Kolanlamil Jakarta Source: Primary data processed from online medias and in-situ survey (2017).

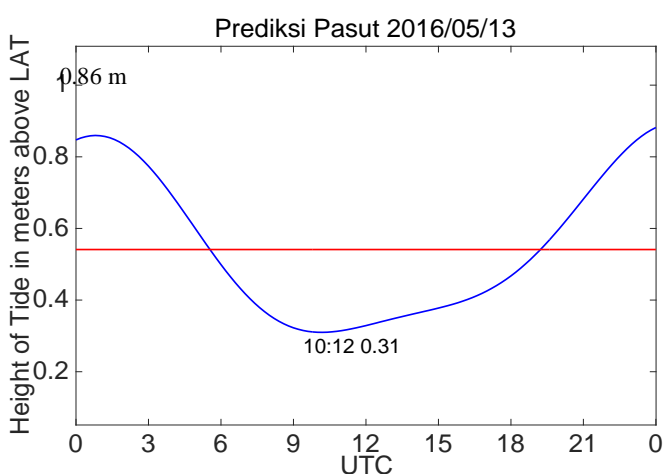

(a)

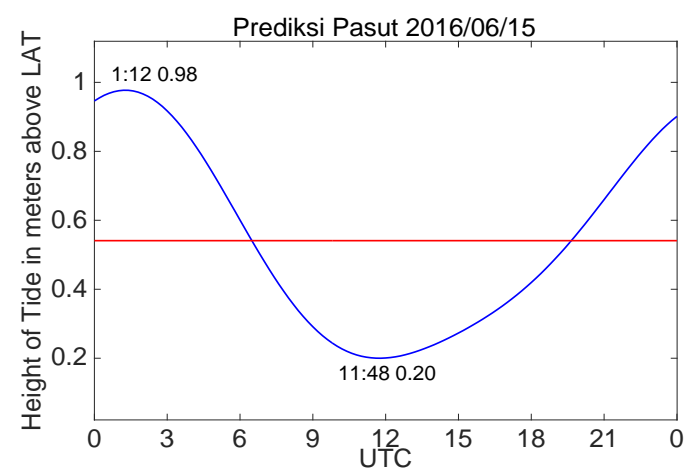

(c)

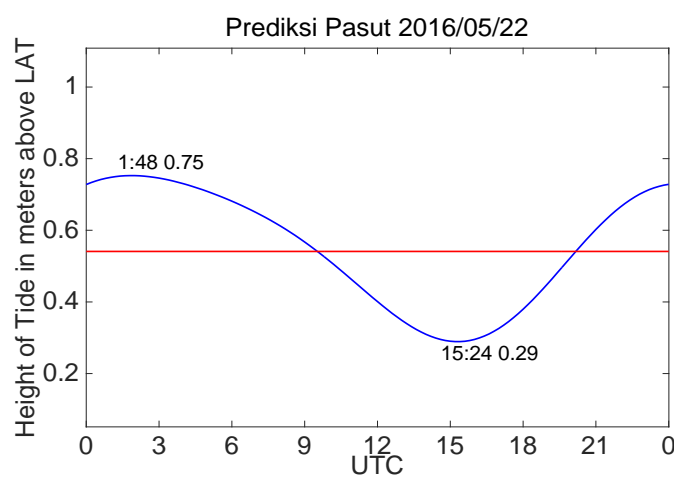

(b)

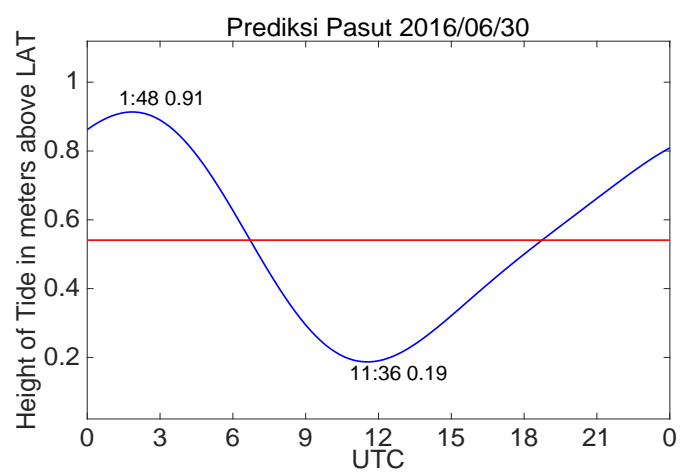

(d) 


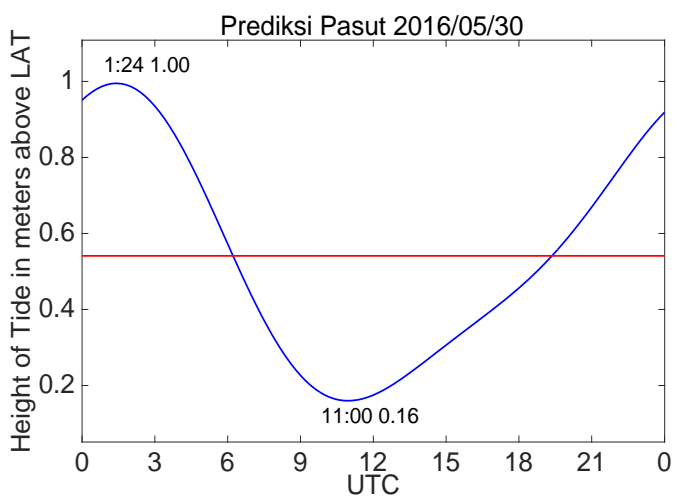

(e)

Figure 11. Graph of daily tide prediction for the acquisition of Landsat 8: (a) 13/5/2016, and (e) 30/6/2016; Acquisition of Sentinel 1A: (b) 22/5/2016, (c) 30/5/2016, and (d) 15/6/2016 in Jakarta.

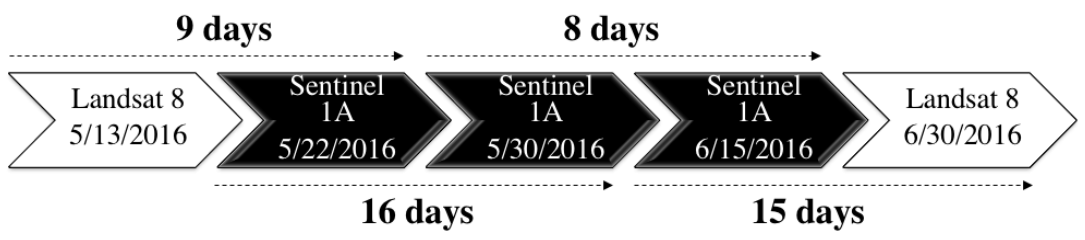

Figure 12. Baseline multi-temporal acquisition of Landsat 8 and Sentinel 1A data used to monitor inundation in Jakarta.

\subsection{Baseline Data Multi-Temporal Landsat 8 dan Sentinel $1 \mathrm{~A}$}

Hasil penelitian menunjukkan bahwa dinamika penggenangan di wilayah pesisir Jakarta dipantau dengan baik melalui kombinasi multi temporal data multi-satelit Landsat 8 dan Sentinel 1A. Berdasarkan baseline data multi-temporal pada Figure 12 menunjukkan bahwa kombinasi multi temporal data akuisisi cukup efektif untuk memantau dinamika genangan di Jakarta. Waktu liput ulang atau resolusi temporal data Landsat 8 (blok putih) dalam penelitian ini cukup lebar hingga mencapai 49 hari (13 Mei 2016-30 Juni 2016), tidak dapat menyajikan informasi dengan lebih akurat dari kejadian banjir rob di Jakarta yang berlangsung sekitar 7 hari. Baseline data Sentinel 1A yang berkisar 8 dan 16 hari dapat mengatasi kesenjangan informasi yang tidak tersedia pada Landsat 8. Hasil studi juga menunjukkan bahwa jeda temporal data kombinasi Landsat 8 dan Sentinel 1A selama 9-15 hari cukup efektif untuk memantau dinamika penggenangan. Baseline data Sentinel 1A (blok hitam) lebih efektif memantau genangan yang berlangsung selama 8-16 hari.

\section{KESIMPULAN}

Penerapan pengindraan jauh sistem optik dari satelit Landsat 8 dan Synthetic Aperture Radar (SAR) Sentinel 1A merupakan salah satu kombinasi terbaik dari dua satelit dengan kemampuan sistem deteksi dan waktu liputan yang berbeda. Hasil ekstraksi kenampakan menunjukkan kedua jenis sensor satelit meningkatkan pemantauan informasi dinamika spasial dan temporal dari genangan air permukaan secara cepat di wilayah tropik Jakarta. Penerapan model Dynamic Surface Water Extent (DSWE) dengan nilai threshold reflektansi air > 0,123 
dan koefisien backscaterring air $-19 \mathrm{~dB}$ berdasarkan polarisasi Vertikal Vertikal (VV) dan Vertikal Horisontal (VH) dapat memetakan dengan baik penggenangan air permukaan di sepanjang pantai, waduk, tanggul, ekosistem mangrove dan lahan terbangun di wilayah pesisir Jakarta sejak akhir Mei 2016 hingga akhir Juni 2016. Gabungan waktu liput ulang kedua jenis sensor satelit menunjukkan baseline berkisar 8-49 hari. Baseline 8-16 hari dari data SAR Sentinel 1A cukup efektif menunjang informasi dari Landsat 8 dengan baseline area studi relatif lama dengan cakupan awan cukup tinggi.

\section{DAFTAR PUSTAKA}

Abidin, H.Z., H. Andreas, I. Gumilar, \& I.R.R. Wibowo. 2015. On correlation between urban development, land subsidence and flooding phenomena in Jakarta. Proc. IAHS, 370: 15-20. https://doi.org/10.5194/piahs-370-152015

Ali, M. 2016. Akibat banjir listrik di pemukiman pantai Mutiara padam. 4 Juni 2016; 01:24 WIB.

https://www.liputan6.com/news/read/ 2523156/akibat-banjir-listrik-dipermukiman-pantai-mutiara-padam.

Amitrano, D., G. Di Martino, A. Iodice, F. Mitidieri, M.N. Papa, D. Riccio, \& G. Ruello. 2014. Sentinel-1 for Monitoring Reservoirs: A Performance Analysis. Remote Sens., 6: 10676-10693. https://doi.org/10.3390/rs61110676

Anggraini, N., B. Trisakti, \& T.E.B. Soesilo. 2012. Pemanfaatan data satelit untuk analisis potensi genangan dan dampak kerusakan akibat kenaikan muka air laut. J. Pengindraan Jauh \& Pengolahan Data Citra Digital, 9(2): 140-150.

http://jurnal.lapan.go.id/index.php/jur nal_inderaja/article/view/1788
Betbeder, J., S. Rapinel, Corpetti, E. Pottier, S. Corgne, \& L. Hubert-Moy. 2014. Multitemporal classification of TerraSAR-X data for wetland vegetation mapping. J. Appl. Remote Sens., 8: 1-16. https://doi.org/10.1117/1.JRS.8.0836 48

Boon. 2007. World Tides User Manual Version 1.03. USA.24 p.

Brisco, B., M. Kapfer, T. Hirose, B. Tedford, \& J. Liu. 2011. Evaluation of C-band polarization diversity and polarimetry for wetland mapping. Can. J. Remote Sens., 37: 82-92. https://doi.org/10.5589/m11-017

Carroll, M.L. \& T.V. Loboda. 2017. Multidecadal surface water dynamics in North American Tundra. Remote Sens., 9(5): 497. https://doi.org/10.3390/rs9050497

Cazals, C., S. Rapinel, P.L. Frison, A. Bonis, G. Mercier, C. Mallet, S. Corgne, \& J.P. Rudant. 2016. Mapping and Characterization of Hydrological Dynamics in a Coastal Marsh Using High Temporal Resolution Sentinel1A Images. Remote Sens., 8(7): 570. https://doi.org/10.3390/rs8070570

Congedo, L. 2016. Semi-automatic classification plugin documentation. Release 6.0.1.1. 198p. https://doi.org/10.13140/RG.2.2.2947 4.02242/1

DeVries, B., C. Huang, M.W. Lang, J.W. Jones, W. Huang, I.F. Creed, \& M.L. Carroll. 2017. Automated quantification of surface water inundation in Wetlands Using Optical Satellite Imagery. Remote Sens., 9(8): 807. https://doi.org/10.3390/rs9080807

Du, Z., W. Li, D. Zhou, L. Tian, F. Ling, H. Wang, Y. Gui, \& B. Sun. 2014. Analysis of Landsat-8 OLI imagery for land surface water mapping. Remote Sens. Lett, 5(7): 672-681. https://doi.org/10.1080/2150704X.20 
14.960606

Ferretti, A., A. Monti-Guarnieri, C. Prati, F. Rocca, \& D. Massonnet. 2007. InSAR Principles: Guidelines for SAR Interferometry Processing and Interpretation. ESA Publications, TM-19. 40p.

https://www.esa.int/esapub/tm/tm19/ TM-19_ptA.pdf

Hall-Atkinson, C. \& L.C. Smith. 2001. Delineation of delta ecozones using interferometric SAR phase coherence: Mackenzie River Delta, NWT. Can. Remote Sens. Environ., 78: 229-238.

https://doi.org/10.1016/S0034-

4257(01)00221-8

Huang, C., Y. Chen, \& J. Wu. 2014. Mapping spatio-temporal flood inundation dynamics at large river basin scale using time-series flow data and MODIS imagery. Int. J. Appl. Earth Obs. Geoinf., 26(1): 350362.

https://doi.org/10.1016/j.jag.2013.09. 002

Irons, J.R., J.L. Dwyer, \& J.A. Barsi. 2012. The next Landsat satellite: The Landsat Data Continuity Mission. Remote Sens. Environ., 122: 1-21. https://doi.org/10.1016/j.rse.2011.08. 026

Jamalludin, K.I. Fatoni, \& T.M. Alam. 2016. Identifikasi banjir rob periode 20132015 di Kawasan Pantai Utara Jakarta. J. Chart Datum, 2(2): 105116.

https://doi.org/10.37875/chartdatum. v2i2.97

Ji, L., L. Zhang, \& B. Wylie. 2009. Analysis of dynamic thresholds for the normalized difference water index. Photogramm. Eng. Remote Sens., 75: 1307-1317.

https://doi.org/10.14358/PERS.75.11. 1307

Jones, J.W. 2015. Efficient wetland surface water detection and monitoring via landsat: comparison with in situ Data from Everglades Depth Estimation Network. Int. J. Remote Sens., 7: 12503-12538.

https://doi.org/0.3390/rs70912503

Lang, M.W. \& E.S. Kasischke. 2008. Using c-band synthetic aperture radar data to monitor forested wetland hydrology in Maryland's Coastal Plain, USA. IEEE Trans. Geosci. Remote Sens., 46(2): 535-546. https://doi.org/10.1109/TGRS.2007.9 09950

McFeeters, S.K. 1996. The use of the Normalized Difference Water Index (NDWI) in the delineation of open water features Int. J. Remote Sens., 17: $1425-1432$. https://doi.org/10.1080/01431169608 948714

Novak, L.M. \& C.M. Netishen. 1992. Polarimetric Synthetic Aperture Radar Imaging. Int J Imaging Syst Technol., 4: 306-318. https://doi.org/10.1002/ima.1850040 410

Ouma, Y.O. \& R. Tateishi. 2006. A water index for rapid mapping of shoreline changes of five East African Rift Valley lakes: An empirical analysis using Landsat TM and ETM+ data. Int. J. Remote Sens., 27: 3153-3181. https://doi.org/10.1080/01431160500 309934

O'Grady, D., M. Leblanc, \& A. Bass. 2013. Relationship of local incidence angle with satellite radar backscatter for different surface conditions. Int $J$ App Ear Obs Geoinf., 24: 42-53. https://doi.org/10.1016/j.jag.2013.02. 005

O’Grady, D., M. Leblanc, \& A. Bass. 2014. The use of radar satellite data from multiple incidence angles improves surface water mapping. Remote Sens Env., 140: 652-664. https://doi.org/10.1016/j.rse.2013.10. 006 
Potin, P., B. Rosich, J. Roeder, \& P. Bargellini. 2014. Sentinel-1 mission operations concept In Proc. IEEE IGARSS. $1465-1468 \mathrm{pp}$.

Ramdhani, J. 2017. Warga sebut tanggul jebol di Muara Angke sejak Mei 2016. 10 Januari 2017; 13:22 WIB. https://news.detik.com/berita/d3392121/warga-sebut-tanggul-jeboldi-muara-angke-sejak-mei-2016.

Rignot, E. \& J. Mouginot. 2012. Ice flow in Greenland for the international polar year 2008-2009. Geophys. Res. Lett., 39: L11501. https://doi.org/10.1029/2012GL0516 34

Schubert, A., D. Small, N. Miranda, D. Geudtner, \& E. Meier. 2015. Sentinel-1A Product Geolocation Accuracy: Commissioning Phase Results. Remote Sens., 7: 9431-9449. https://doi.org/10.3390/rs70709431

Schumann, G.J.P. \& D.K. Moller. 2015. Microwave remote sensing of flood inundation, Phys Chem Earth, 83-84: 84-95.

https://doi.org/10.1016/j.pce.2015.05. 002

Simarmata, H.A. 2018. Phenomenology in adaptation planning an empirical study of flood-affected people in Kampung Muara Baru Jakarta. Springer. Singapore. 203p.

Sutrisno, D., R. Windiastuti, I. Sofyan, \& D. Ramdhani. 2011. Spatial Modeling of Sea Level Rise Projections for Health Vulnerability Estimation. Globë, 13(2): 102-111.

http://jurnal.big.go.id/index.php/GL/a rticle/view/92/89

Sundermann, L., O. Schelske, \& P. Hausmann. 2014. Mind the risk-A global ranking of cities under threat from natural disasters. Swiss Re. Zurich, Swiztzerland. 30 p.

Takagi H., D. Fujii, M. Esteban, \& X. Yi. 2017. Effectiveness and limitation of coastal dykes in Jakarta: The Need for Prioritizing Actions against Land Subsidence. Sust., 9(4): 619. http://doi.org/10.3390/su9040619.

$\mathrm{Xu}, \mathrm{H}$. 2006. Modification of normalised difference water index (NDWI) to enhance open water features in remotely sensed imagery. Int. J. Remote Sens., 27: 3025-3033. https://doi.org/10.1080/01431160600 589179

White, L., B. Brisco, M. Dabboor, A. Schmitt, \& A. Pratt. 2015. A Collection of SAR Methodologies for Monitoring Wetlands Remote Sens., 7: 7615-7645. https://doi.org/10.3390/rs70607615

Wibowo, A. 2012. Kerentanan lingkungan laut tiap provinsi di Indonesia. $J$. Ilmu dan Teknologi Kelautan Tropis, 4(1): 145-162. https://doi.org/10.29244/jitkt.v4i1

Yusuf, A.A. \& H.A. Francisco. 2009. Climate Change Vulnerability Mapping for Southeast Asia. 26p. http://www.eepsea.org/pub/tr/123241 96651Mapping_Report.pdf

Received : 20 April 2020

Reviewed : 8 August 2020

Accepted : 28 December 2020 
